\title{
Epidural morphine for outpatients with severe anginal pain
}

\author{
SØREN EIGIL CLEMENSEN， PER THAYSSEN， PETER HOLE
}

\begin{abstract}
Seven patients who had chronic coronary artery disease and had undergone coronary artery bypass surgery still suffered from anginal attacks several times daily despite optimal medical treatment. An epidural system of analgesia was implanted subcutaneously and treatment with epidural morphine started. The morphine was administered by the patients themselves or members of their family. During a median observation time of four months (range three to 11) all patients were free of pain while receiving this treatment.
\end{abstract}

\section{Introduction}

During recent years treatment with epidural and intrathecal morphine has become increasingly popular. Since Wang et al and Behar $e t$ al first described the technique it has been used for pains of various origins-for example, postoperative pain, severe pain owing to gangrene of the legs, and neoplastic pain. ${ }^{12}$ It has also been used in outpatients, with good results. ${ }^{3}$

We report on a new system for long term epidural analgesia (PortA-Cath, Pharmacia) that we tried in outpatients with chronic severe anginal pain who needed intramuscular morphine once or more daily but suffered from unacceptable side effects.

\section{Patients and methods}

Seven patients (median age 55 (range 47-73)) who had chronic coronary artery disease had all undergone coronary artery bypass surgery. They still suffered, however, from anginal attacks several times daily, despite

\section{Odense University Hospital, DK-5000 Odense C, Denmark}

SØREN EIGIL CLEMENSEN, MD, registrar, department of anaesthesia and intensive care

PER THAYSSEN, MD, PHD, senior registrar, department of cardiology

PETER HOLE, MD, consultant, department of anaesthesia and intensive care

Correspondence to: Dr Clemensen. conventional medical treatment ( $\beta$-blockers, calcium blockers, or nitrates or a combination). They all needed opiates enterally or parenterally, or both, daily.

Tables I and II show that six patients had suffered previously from myocardial infarction and that the duration of angina pectoris varied from one to 10 years. They also show data obtained from coronary angiography and left ventriculography before and after the most recent coronary artery bypass grafting. Despite all patients having been fully revascularised during the operation angina pectoris recurred within five months after surgery. After the most recent bypass operation all seven patients were often admitted to hospital because myocardial infarction was suspected. During anginal pain or exercise tests five patients developed ST-T changes.

Initially, an indwelling epidural catheter was inserted in the thoracolumbar region, and treatment with epidural morphine 2-3 mg once or twice daily was started. Pain in all seven patients lessened, so we decided to implant a Port-A-Cath system. An epidural catheter, inserted sub-

TABLE I-Dates of onset of angina pectoris and previous myocardial infarction and results of coronary angiography before operation

\begin{tabular}{|c|c|c|c|c|c|}
\hline \multirow[b]{2}{*}{$\begin{array}{l}\text { Case } \\
\text { No }\end{array}$} & \multirow[b]{2}{*}{$\begin{array}{c}\text { Onset } \\
\text { of } \\
\text { angina }\end{array}$} & \multirow[b]{2}{*}{$\begin{array}{c}\text { Previous } \\
\text { myocardial } \\
\text { infarction }\end{array}$} & \multicolumn{3}{|c|}{ Results of coronary angiography before operation } \\
\hline & & & Coronary artery stenosis $\geqslant 50 \%$ & $\begin{array}{l}\text { Left } \\
\text { ventricular } \\
\text { ejection } \\
\text { fraction }\end{array}$ & $\begin{array}{l}\text { Left ventricular } \\
\text { end diastolic } \\
\text { pressure } \\
(\mathrm{mm} \mathrm{Hg})\end{array}$ \\
\hline 1 & 1977 & 1981 & $\begin{array}{l}\text { Left anterior descending } \\
\text { branch, circumflex branch of } \\
\text { left coronary artery, right } \\
\text { coronary artery }\end{array}$ & 71 & 8 \\
\hline 2 & 1981 & 1979 & $\begin{array}{l}\text { Left anterior descending } \\
\text { branch, circumflex branch of } \\
\text { left coronary artery, right } \\
\text { coronary artery }\end{array}$ & 47 & 8 \\
\hline 3 & 1983 & 1983 & Right coronary artery & 56 & 12 \\
\hline 4 & 1976 & 1978 & $\begin{array}{l}\text { Left coronary artery, left } \\
\text { anterior descending branch, } \\
\text { circumflex branch of left } \\
\text { coronary artery, right } \\
\text { coronary artery }\end{array}$ & 73 & 10 \\
\hline 5 & 1985 & - & Right coronary artery & 71 & 13 \\
\hline 6 & 1978 & 1980 & $\begin{array}{l}\text { Left anterior descending } \\
\text { branch, circumflex branch of } \\
\text { left coronary artery, right } \\
\text { coronary artery }\end{array}$ & 33 & 15 \\
\hline 7 & 1978 & 1978 & $\begin{array}{l}\text { Left coronary artery, left } \\
\text { anterior descending branch, } \\
\text { circumflex branch of left } \\
\text { coronary artery, right } \\
\text { coronary artery }\end{array}$ & 49 & 16 \\
\hline
\end{tabular}


cutaneously between the 12th thoracic and the first lumbar vertebrae, was connected to the capsule, which was placed in the lower anterior left or right side of the thorax (figure). Having instructed the patients in the injection technique we adjusted the doses of morphine to the lowest possible. The patients left the hospital without any instructions to restrict their physical activity.

TABLE II-Date of coronary artery bypass operation, degree of revascularisation, time from operation to recurrence of angina, and results of most recent coronary angiography

\begin{tabular}{|c|c|c|c|c|c|c|}
\hline \multirow[b]{2}{*}{$\begin{array}{l}\text { Case } \\
\text { No }\end{array}$} & \multirow[b]{2}{*}{$\begin{array}{l}\text { Coronary } \\
\text { bypass } \\
\text { operations }\end{array}$} & \multirow[b]{2}{*}{$\begin{array}{c}\text { Fully } \\
\text { revas- } \\
\text { cularised }\end{array}$} & \multirow[b]{2}{*}{$\begin{array}{l}\text { Onset of } \\
\text { angina after } \\
\text { operation } \\
\text { (months) }\end{array}$} & \multicolumn{3}{|c|}{ Results of most recent coronary angiography } \\
\hline & & & & Closed bypass & $\begin{array}{c}\text { Left } \\
\text { ventricular } \\
\text { ejection } \\
\text { fraction }\end{array}$ & $\begin{array}{c}\text { Left ventricular } \\
\text { end diastolic } \\
\text { pressure } \\
(\mathrm{mm} \mathrm{Hg})\end{array}$ \\
\hline 1 & $\begin{array}{l}1977 \\
1981\end{array}$ & + & $<1$ & & 62 & 11 \\
\hline 2 & $\begin{array}{l}1982 \\
1983\end{array}$ & + & $<1$ & $\begin{array}{l}\text { Left anterior } \\
\text { descending } \\
\text { branch, right } \\
\text { coronary artery }\end{array}$ & 48 & 7 \\
\hline 3 & 1983 & + & $<2$ & $\begin{array}{l}\text { Right coronary } \\
\text { artery }\end{array}$ & 61 & 12 \\
\hline 4 & $\begin{array}{l}1977 \\
1978 \\
1986\end{array}$ & + & $<5$ & & & \\
\hline 5 & 1985 & + & $<1$ & $\begin{array}{l}\text { Right coronary } \\
\text { artery }\end{array}$ & 70 & 6 \\
\hline 6 & 1981 & + & $<5$ & & & \\
\hline 7 & 1979 & + & $<4$ & $\begin{array}{l}\text { Circumflex branch } \\
\text { of left coronary } \\
\text { artery, right } \\
\text { coronary artery }\end{array}$ & 60 & 7 \\
\hline
\end{tabular}

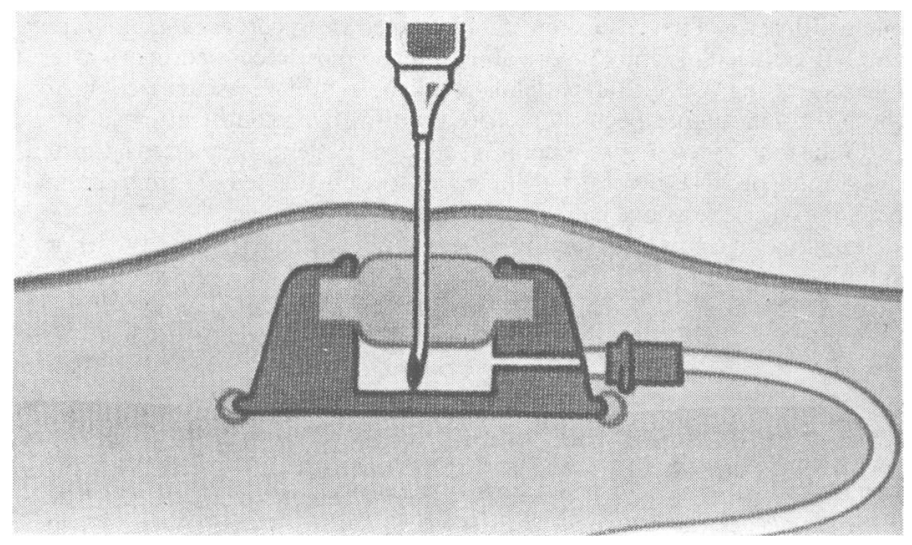

Subcutaneous implantation of injection portal.

TABLE III-Age of patients, median observation time, and doses of morphine administered

\begin{tabular}{lccc}
\hline $\begin{array}{l}\text { Case } \\
\text { No }\end{array}$ & $\begin{array}{c}\text { Age } \\
\text { (years) }\end{array}$ & $\begin{array}{c}\text { Observation time } \\
\text { (months) }\end{array}$ & $\begin{array}{c}\text { No of morphine } \\
\text { doses administered }\end{array}$ \\
\hline 1 & 50 & 11 & $3 \times 3 \mathrm{mg}$ \\
2 & 55 & 8 & $3 \times 3 \mathrm{mg}$ \\
3 & 47 & 6 & $2 \times 3 \mathrm{mg}$ \\
4 & 68 & 4 & $1 \times 21 \frac{\mathrm{mg}}{2 \times 2 \mathrm{mg}}$ \\
5 & 55 & 3 & $3 \times 4 \mathrm{mg}$ \\
6 & 67 & 3 & $2 \times 2 \mathrm{mg}$ \\
7 & 65 & 3 & \\
\hline
\end{tabular}

\section{Results}

Anginal pain in all seven patients lessened. Before the onset of angina three patients had been very active, and they now restarted their normal physical activities. One of the patients was still limited because of arthrosis of his hip. The three other patients remained free of chest pain at the end of three months. Table III shows the durations of observation and doses of morphine.

\section{Discussion}

Reports on epidural analgesia with opiates for angina pectoris have not to our knowledge been published before, though epidural analgesia for inpatients who have had myocardial infarction has been successfully carried out. ${ }^{4}$ The results of the present study show that such treatment is a realistic solution for patients with angina who still suffer from pain while receiving conventional medical treatment with either $\beta$-blocking agents, calcium blockers, or nitrates, or a combination. Furthermore, in the Port-A-Cath system the patients or their relatives can administer the morphine themselves through an epidural catheter connected by a subcutaneous silicone catheter to a capsule in a specially made subcutaneous pocket in the upper abdomen or the lower thorax. The system can be implanted in patients under either general or local anaesthesia. The subcutaneous capsule is easy to locate and has a silicone membrane that can withstand about 2000 punctures.

Though traditional systems of epidural analgesia might be used in outpatients provided with a bacterial filter, they can lead to various complications as infections, kinking, or skin reactions. The number of patients who have angina pectoris and who need such treatment is difficult to evaluate. Generally, patients with angina pectoris, despite medical treatment, are subjected to coronary angiography in preparation for coronary bypass surgery. In about one fifth of these patients it is impossible to carry out this treatment for technical reasons. ${ }^{5}$ Furthermore, of those patients undergoing coronary artery bypass surgery, about $15-20 \%$ still suffer from angina pectoris of varying severity after operation, despite medical treatment. ${ }^{6}$

The reports that we have studied seem unable to give any rough figures for the number of patients who need morphine daily or who suffer side effects from such treatment, or both. The number of such patients may also depend on local traditions for treatment of such patients with "chronic" anginal pains. A cautious estimate of the incidence of patients with chronic angina in Denmark might be 100 a year. In these patients the technique that we have described seems to be a realistic alternative or supplementary treatment for patients who suffer from angina pectoris and need morphine. Further studies are planned of electrocardiographic changes during exercise and changes in arterial catecholamine concentrations before and after epidural morphine.

\section{References}

1 Wang JK, Nauss LE, Thomas JE. Pain relief by intrathecally applied morphine in man. Anesthesiology 1979;50:149-50.

2 Behar M, Magora F, Olshwang D, Davidsson JT. Epidural morphine in treatment of pain. Lance 1979;i:527-9.

3 Cherry DA, Gourlay KG, Cousins JM, Gannon JB. A technique for insertion of an implantable portal system for the longterm epidural administration of opioids in the treatment of cancer pain. Anaesth Intensive Care 1985;13:145-52.

4 Skoeld $M$, Gillberg $L$, Ohlsson $O$. Pain relief in myocardial infarction after continuous epidural morphine analgesia. $N$ Engl f Med 1985;312:650.

5 Gross H, Vaid AK, Cohen MV. Prognosis in patients rejected for coronary revascularization surgery. Am f Med 1978;64:9-20.

6 European Coronary Surgery Study Group. Long-term results of prospective randomized study of coronary artery bypass surgery in stable angina pectoris. Lancet 1982;ii:1173-80.

(Accepted 11 December 1986) 